\title{
Greenhouse Tests with Nematocides for Control of Nematodes Attacking Tomato (Lycopersicon esculentum var. Rutgers) in Puerto Rico
}

\author{
Alejandro Ayala \\ INTRODUCTION
}

Tomato, Lyocopersicon esculentum Mill. ranges among the most susceptible plants to the attacks of root-knot nematodes, Meloidogyne spp. in Puerto Rico. It has been found infected with these parasites everywhere the plants are grown, regardless of soil type, varying moisture conditions, or altitude. Although several reports have been made of root-knot attacks on tomatoes and other crops on the Island $(1,3,4,5)^{2}$, no attempts were made to identify the species present or to develop control measures.

Recently, tomato plantings also have been found heavily attacked by the reniform or kidney-shaped nematode, Rotylenchulus reniformis Linford and Oliveira, 1940. Many other forms such as meadow nematodes, Pratylenchus spp., ring nematodes, Criconemoides spp., bulb and stem nematodes, Dilylenchus spp., spiral nematodes, Helicotylenchus nannus Steiner, 1945, H. erythrinae (Zimmerman, 1904) Golden, 19:56 and H. multicinctus (Cobb, 189:3) Golden, 19:6, dagger nematodes, Xiphinema spp., and needle nemutodes, Longidorus spp., also Tylenchus, Aphelenchus, Aphelenchoides, Seinura, Paraphelenchus, Metaphelenchus, Hoplolaimus, and Hemicriconemoides spp. have been observed in scattered samples, but are considered of lesser importance because they do not usually occur in large numbers.

Tests of a preliminary nature conducted in both sterile and infected soil in the greenhouse, as well as several samples taken in the field showed that the two most abundant nematode species attacking tomato in Puerto Rico are Meloidogyne incognita (Kofoid and White 1919) Chitwood 1949, and Rotylenchulus reniformis, and presumably these constitute a main factor in its growth and production. Stunted growth accompanied by chlorosis and wilting was characteristic of infected plants. These symptoms became evident particularly at blossoming time after which plants rapidly lost vigor and eventually died. Control plants remained normal. Several chemical-control experiments failed to show differences in crop yield because many factors interfered. Many of our soils are heavy, which makes difficult

${ }^{1}$ Research Assistant in Nematology, Agricultural Fxperiment Station, University of Puerto Rico, Río Piedras, P.R. In the preparation of this paper the writer is deeply indebted to the late Dr. G. Steiner, and to Irs. M. F. P'érez and L. F. Martorell, for their suggestions and criticisms and their aid in correcting manuscripts.

2 Italic numbers in parentheses refer to Literature Cited, p. 327. 
the penetration of fumigants. Furthermore, the high temperature prevalent in the soil promotes rapid evaporation of fumes, thus reducing the nematocidal effects of fumigants applied. This is especially pronounced when the moisture content of the soil is low.

Controlled experiments were deemed necessary in order to obtain data useful in comparing the effects of several chemicals. For this purpose an experiment was performed in the greenhouse using one of the most susceptible varieties of tomato: Rutgers. In this experiment chemicals were tested either to study their effects on the nematode populations or their phytotoxicity, if any.

\section{MATERIALS AND METHODS}

The soil used, a Bayamón sandy clay, was brought from a pineapple farm in Manatí, where "cadillo", Urena lobata L. (a common weed growing in this soil) was heavily infected with Meloidogyne incognita and Rotylenchulus reniformis, as well as several other nematode species. This soil was thoroughly mixed with steam-sterilized soil rich in organic matter, to which fertilizer had been added previously. Eight wooden boxes were filled with the mixed soil.

A compound sample from each was processed in the laboratory for determination of the nematode species present and their abundance. A modification of the Baermann-funnel method as described by Christie and Perry (2) was used. Each of eight boxes was treated with 2 cc. per square feet, or 20 gallons per acre, of the fumigants D-D, EDB, DCB-60, Dorlone, Telone, Fumazone, Nemagon, and Vapam, and were closed tightly. The soil for the controls was kept in a closed cardboard hox.

After 15 days the boxes were opened and the contents of each emptied into five 8-inch flowerpots. The pots were then set up in a greenhouse bench and left undisturbed for 15 more days to insure disappearance of any toxic fumes. A posttreatment soil sample was processed to determine the effects of each of the treatments. The nematode species present were identified as to genus and, in some cases, as to species, and their numbers recorded. Sterile-grown seedlings of the Rutgers variety were then transplanted in each pot.

Seedlings measuring an average of 4 inches (range 2.75 to 5.00 ) at the time of transplanting were used. Measurements were conducted every 3 to 4 days until the fifty-eighth day after planting (88 days after treatment). No additional application of fertilizer was made and water was applied every day as needed.

The plants were dug after 58 days, when the final observations and measurements were made. Most of them were then blooming or in fruit. The stem of each plant was cut at the soil level and weighed. The roots 
were washed, weighed, and evaluated as to degree of root-knot infection, general appearance and intensity of secondary-root formation. The following degrees of root-knot infection or galling were considered in evaluating samples: 0 , No infection; 1 , very light infection; 2 , light infection; 3 , medium infection; 4, high infection; and 5, very high infection. Besides this, the color and appearance of the plants were taken into consideration for the general conclusions. Fruiting had not been completed at the treatment evaluation. Nevertheless yield data were recorded.

\section{OBSERVATIONS AND DISCUSSION}

Growth curves are presented in figure 1 for only three of the chemicals tested (Dorlone, EDB, and Nemagon) and the control. These three chemicals were the only fumigants whose results were statistically superior to the control. As figure 1 shows, the difference in growth in the fumigated soil and in the control became larger as the plants got older, up to blossoming time, when the differences were the largest. The EDB- and Nemagontreated plants were very tender and thin, indicating a phytotoxicity of the chemicals at high dosages. There is no doubt that, if used at the rate of 20 gallons per acre, Nemagon and EDB are toxic to tomato. Dorlone and Nemagon were statistically superior to the control at the 1-percent level, whereas EDB was significantly superior only at the 5-percent level.

DCB-60 was severly phytotoxic, as demonstrated by the death of 40 percent of the plants before blooming. The plants in some of the other treatments, although not as tall as those under Dorlone treatment, were healthy and strong. The control plants were stout and looked healthy, showing very slight wilting symptoms. This result is in accord with previous observations that it is not until the first fruits are produced by the tomato that pronounced symptoms of nematode damage are noticed on the aboveground parts of the tomato plants in Puerto Rico. It is at this time that chlorosis, stunting, and wilting symptoms become evident. These symptoms are noticed in plants that produce fewer and smaller fruits; plants attacked by nematodes eventually die sooner than healthy ones.

Table 1 shows the observations made at harvesting time. The Dorlonetreated plants wejghed more than any of the others and plants from the DCB-60 weighed the least. The weight of the roots was higher in the control and in Vapam-treated plants. It was under these treatments that root-knot infection was higher and caused an abnormal production of secondary roots and galls (fig. 2). The roots of the Nemagon- and EDBtreated plants were few and showed a brownish color which was interpreted as a sign of toxicity.

The degree of root-knot galling varied greatly between treatments. No galls were observed on roots from the EDB, Dorlone, Nemagon and D-D 


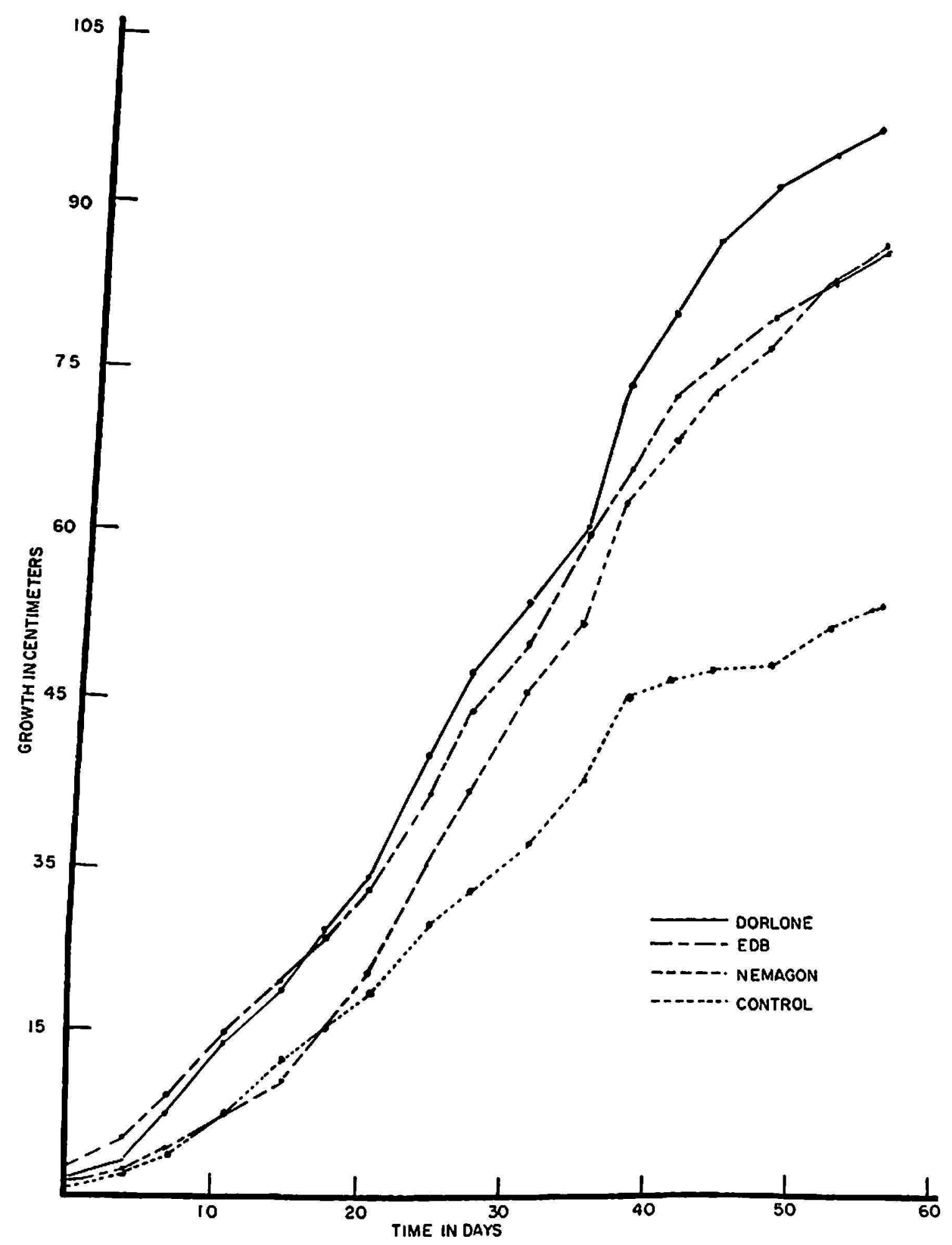

Fig. 1.-Average increase in apical growth of tomato plants used in experimental control of parasitic nematodes.

treatments. Twenty percent of the plants from the Fumazone and Telone treatments showed some gall formation on their roots. On the other hand, 100-percent infection was obtained with DCB-60, Vapam, and the control. The average reading of degree of infection for all treatments is shown in table 1. 
Although plants were dug before completion of fruiting, some differences in number and weight of fruits were noticed between the Dorlone-treated plants and some of the other fumigants. The difference between Dorlone and the control was outstanding.

TABLE 1.-Data obtained from the experiment with 8 different nematorides against root-knot and reniform nematodes in tomatoes

\begin{tabular}{l|c|c|c|c|c|c}
\hline \multicolumn{1}{c|}{ Nematocide } & $\begin{array}{c}\text { Weight of stems } \\
\text { and leaves }\end{array}$ & $\begin{array}{c}\text { Weight of } \\
\text { roots }\end{array}$ & Height of stems & Fruits & $\begin{array}{c}\text { Weight of } \\
\text { fruits }\end{array}$ & $\begin{array}{c}\text { Degre of } \\
\text { root-knot } \\
\text { galling }\end{array}$ \\
\hline & $G m$. & $G m$. & $C m$. & Ntmber & Gm. & \\
D-D & 340.20 & 7.5 & 78.75 & 7 & 113.40 & 0 \\
EDB & 311.85 & 7.0 & 95.50 & 6 & 62.79 & 0 \\
Telone & 382.73 & 10.0 & 84.00 & 7 & 99.23 & 1 \\
Dorlone & 498.13 & 8.6 & 107.50 & 11 & 155.93 & 0 \\
Fumazone & 382.73 & 7.3 & 88.75 & 7 & 127.58 & 1 \\
DCB-(i0 & 297.68 & 8.7 & 91.50 & 6 & 42.53 & 3 \\
Vapam & 431.34 & 12.9 & 80.50 & 8 & 113.40 & 3 \\
Nemagon & 403.98 & 6.2 & 96.25 & 8 & 78.28 & 0 \\
Control & 340.20 & 23.7 & 62.75 & 2 & 7.03 & 5 \\
\hline
\end{tabular}

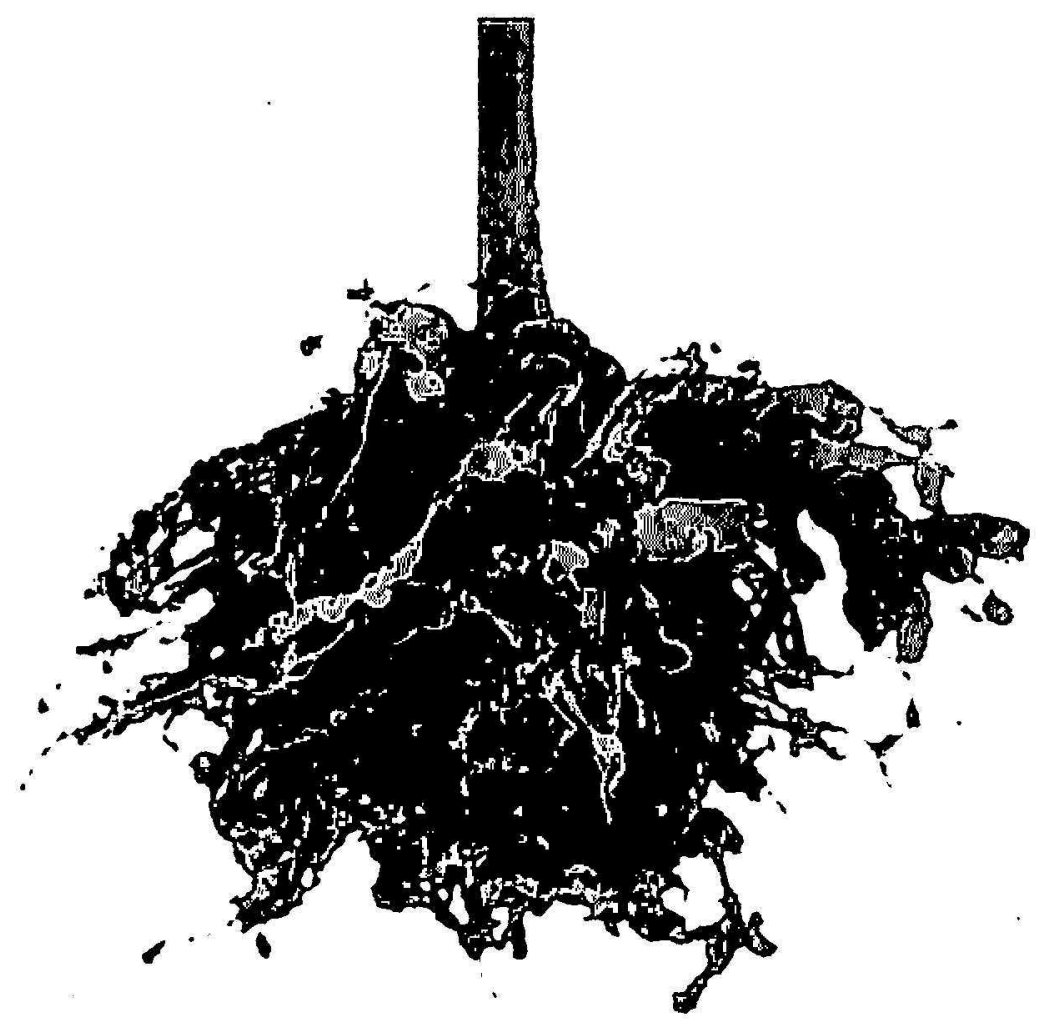

Fia. 2.-Representative tomato root-system from a control plant. Notice tremendous number of galls caused by the root-knot nematodes. 
Table 2 shows the nematode populations of the two most important species and the total of all genera found in the samples before treating and at 58 days after planting, i.e., at harvesting time. Fifteen genera were represented, three of which were present in all the samples before fumigation, e.g., Meloidogyne incognita, Rolylenchulus reinformis, and Dorylaimus spp. The rest of the genera were found in few samples and represented by small numbers of specimens.

The populations of the root-knot nematodes were greatly reduced by the treatments with D-D, EDB, Dorlone, and Nemagon. These four, as

TABI.E 2.-Comparison of nematode populations before fumigation and at harvesting time of lomaloes when specified nemalocides were used

\begin{tabular}{|c|c|c|c|c|c|c|c|c|c|}
\hline \multirow{4}{*}{ Nematocide } & \multicolumn{9}{|c|}{ Nematode populations } \\
\hline & \multicolumn{3}{|c|}{ Meloidogyne incognila } & \multicolumn{3}{|c|}{ Rolylenchuitus reniformis } & \multicolumn{3}{|c|}{ Total of $1 \overline{5}$ genera } \\
\hline & \multirow{2}{*}{$\begin{array}{c}\text { Before } \\
\text { fumigat- } \\
\text { ing }\end{array}$} & \multicolumn{2}{|c|}{ At harvesting time } & \multirow{2}{*}{$\begin{array}{c}\text { Before } \\
\text { fumigat- } \\
\text { ing }\end{array}$} & \multicolumn{2}{|c|}{$\begin{array}{c}\text { At harvesting } \\
\text { time }\end{array}$} & \multirow{2}{*}{$\begin{array}{c}\text { Before } \\
\text { fumigat- } \\
\text { ing }\end{array}$} & \multicolumn{2}{|c|}{ At harvesting time } \\
\hline & & Soill & Roots2 & & Soilı & Roots? & & Soil1 & Roots: \\
\hline D-D & 200 & 0 & 11 & 570 & 0 & 0 & 2,510 & 143 & 15 \\
\hline EDB & 546 & 0 & 0 & 951 & 0 & 0 & 2,559 & 58 & 5 \\
\hline Telone & 228 & 86 & 2 & 827 & 0 & 0 & 2,682 & 115 & 1,036 \\
\hline Dorlone & 270 & 0 & $\mathbf{0}$ & 399 & 0 & 0 & 2,252 & 399 & 58 \\
\hline Fumazone & 1,254 & 57 & 342 & 1,254 & 0 & $\mathbf{0}$ & 3,793 & 57 & 342 \\
\hline DCB-60 & 285 & 428 & 4,959 & 646 & 429 & 57 & 1,273 & 877 & 5,073 \\
\hline Vapam & 143 & 599 & 4,191 & 421 & 1,354 & 0 & 1,847 & 2,695 & 4,229 \\
\hline Nemagon & 342 & 0 & 0 & 684 & 0 & 0 & 4,229 & 201 & 2 \\
\hline Control & 228 & 1,482 & 15,163 & 542 & 995 & 0 & 1,768 & 3,878 & 15,250 \\
\hline
\end{tabular}

1 Nematodes present in 300 cc. of soil.

2 Nematodes present in $50 \mathrm{gm}$. of roots.

well as Telone and Fumazone, controlled the reniform nematode, $R$. reniformis 100 percent. Although some larvae of the root-knot nematode were recovered from the D-D and EDB plants at harvesting time, no females or galls were ohserved in the roots.

Many specimens of the other genera present appeared only after fumigation, or at harvesting time. This can be explained either by the fact that a small sample of 300 'cc. of soil was processed and these nematodes could escape detection before fumigation, or that only eggs were present when the first samples were taken. Hatching could have taken place after planting the tomato seedlings. The previously observed slow action of Nemagon was noticed again with the recovery of several nematodes 30 days after fumigation, but not 88 days after. 
Studying the total number of nematodes present we find again that D-D, EDB, Dorlone, Nemagon, and Fumazone gave the best results, and that DCB-60 and Vapam at the dosage of 2 cc. per square feet (around 20 gallons per acre) were not effective. The populations of the two most important species, e.g. $M$. incognita and $R$. reniformis, were exceedingly high on the control plants. Dorylaimus spp. and Aphelenchus spp. were also present, although not in great numbers, but these genera are of doubtful significance as plant feeders.

\section{SUMMARY}

It has been found that, in Puerto Rico, tomatoes are severely attacked by several species of plant parasitic nematodes and particularly by Meloidogyne incognita (the root-knot nematode) and Rotylenchulus reniformis, the reniform or kidney-shaped nematode. Several experiments were conducted to determine the efficacy of different nematocides against these pests. The last experiment conducted in the greenhouse using eight different nematocides and one of the most susceptible tomato varieties, Rutgers, is discussed. Evidence presented in the form of graphs and tables demonstrates that at least the four fumigants D-D, Dorlone, EDB, and Nemagon are effective in the control of both species of nematodes mentioned. Two compounds, Telone and Fumazone, although not completely effective against root knot, gave a perfect, control of the reniform nematodes. Dorlone was superior to all other nematocides, giving the best results in relation to growth, weight of stem, yicld, and general appearance of the plants. It also gave perfect control of the reniform and root-knot nematodes. The difference in height of plants over the control was statistically significant at the 5-percent level with EDB and at the 1-percent level with Dorlone and Nemagon. There was no significant statistical difference among the chemicals tested nor between the rest of the chemicals and the control.

The severity of root-knot infection varied from degree 0 , no infection, to degree 5, very high infection. Root knot was outstanding in the control plants, which showed a very high infection average of degree 5 for galling. At time of harvesting the plants were smaller than those under all the other treatments, but exhibited very little chlorosis and yellowing. In previous trials symptoms developed to a maximum only after blooming or the first picking of fruits. Blooming was retarded, which was shown by the small amount and weight of fruits. A very heavy gall and secondary rootformation was observed.

Dorlone gave the best results and showed no phytotoxic effects. Similar observations have been made in field experiments. Phytotoxicity was shown by treatments with Nemagon, EDB, and DCB-60. This condition 
can be avoided using a lower dosage of the first two nematocides. DCB-60 proved to be ineffective.

\section{RESUMEN}

Varias especies de nemátodos parasíticos de plantas, particularmente el Meloidogyne incognita que produce agallas en las raíces y el Rotylenchulus reniformis que tiene forma de riñón, atacan muy severamente las siembras de tomate en Puerto Rico.

Se hicieron distintos experimentos con el objeto de determinar la eficacia de varios nematocidas para controlar estos nemátodos. Aquí se discute el último experimento que incluyó ocho nematocidas distintos y con los cuales se trató el terreno donde se sembraron plantas del tomate variedad Rutgers, una de las más susceptibles al ataque de los nemátodos.

Se presentan cuadros y gráficas para demostrar que, por lo menos, cuatro de los fumigantes aplicados (D-D, Dorlone, EDB y Nemagon), a razón de $2 \mathrm{~cm}$. cúbicos por cada pie cuadrado de terreno, son eficaces para combatir las dos especies de nemátodos arriba mencionados. Se probaron, además, otros dos compuestos químicos (Telone y Fumazone), pero sus efectos no fueron completamente eficaces para controlar el nemátodo de agalla, aunque sí para el reniforme.

Las aplicaciones de Dorlone mejoraron el crecimiento de las plantas, el peso de los tallos y los rendimientos y también mejoraron la apariencia general de las plantas en mayor grado que los otros agentes químicos usados. El Dorlone también fue eficaz para controlar tanto los nemátodos que forman agallas en la raíz como los reniformes.

La diferencia en tamaño de las plantas sobre el testigo fue estadísticamente significativa al nivel del 5 por ciento con EDB y al nivel del 1 por ciento con Dorlone y Nemagon. No hubo diferencia estadística significativa entre los resultados obtenidos de los otros agentes químicos, ni entre el resto de estos últimos y los del testigo.

La incidencia de agallas y nudos en la raíz varió desde el grado 0 , o sea, completa ausencia de infestación, hasta el grado 5, que se considera como el más alto grado de infestación posible. Las plantas del tratamiento testigo demostraron una infestación promedio muy alta del grado 5. Al tiempo de cosecharse, las plantas tenían un tamaño menor que en los demás tratamientos, aunque mostraban muy pocos síntomas de clorosis y amarillez. Se observó en experimentos anteriores que los síntomas se manifestaron plenamente después de la florecida y después de cosecharse las primeras frutas. En esta prueba la florecida se retardó, de ahí que hubiera poca cantidad de frutas de poco peso. También se observó que estas plantas tenían grandes protuberancias en sus raíces y que las raíces secundarias se desarrollaron en número excesivo. 
El Dorlone fue el mejor nematocida, porque controló satisfactoriamente los nemátodos y no produjo efectos fitotóxicos. Anteriormente, se habían hecho observaciones similares en experimentos de campo. Los efectos fitotóxicos se observaron en las plantas cuando se aplicaron Nemagon, EDB y DCB-60. Esta condición, no obstante, puede evitarse si se usa una dósis menor de los dos primeros nematocidas.

El DCB-60 fue ineficaz.

\section{LITERATURE CITED}

1. Ayala, A., Methods of Nematode Control in Puerto Rico, Proceedings of the Shell Nematology Workshop, San Juan, P.R., pp. 49-57, 1959.

2. Christie, J. R., and Perry, V. G., Removing nematodes from the soil, Proc. Helminth. Soc. Wash. 18 106-8, 1951.

3. Cook, M. T., Enfermedades de las Plantas Económicas de las Antillas, Monografía de la Universidad de Puerto Rico, No. 4, p. 416, 1939.

4. Steiner, G., Investigations on the relationship of nematodes to crop production and plant life in Puerto Rico, Agr. Exp. Sta., Univ. P.R., Ann. Rept., pp. 1-10, 1960.

5. Steiner, G., and Ayala, A., Plant Nematodes of Puerto Rico, Distribution of Plant Parasitic Nematodes in the South, Southern Co-op, Ser. Bul. 74 pp. 57-75, 1960. 